\title{
Rotavirus and Cryptosporidium pathogens as etiological proxies of gastroenteritis in some pastoral communities of the Amathole District Municipality, Eastern Cape, South Africa
}

\author{
Luyanda Msolo ${ }^{1,2^{*}} \mathbb{D}$, Benson C. Iweriebor ${ }^{3}$ and Anthony I. Okoh ${ }^{1,2}$
}

\begin{abstract}
Objective: Cryptosporidium and Rotavirus agents have been associated with severe diarrheal illnesses and remain as one of the worst human health burdens in most developing regions. In the present study, we evaluated the incidences of Cryptosporidium and Rotavirus in diarrheal stool specimens of patients in some rural settlements of the Amathole District Municipality in the Eastern Cape Province, South Africa. Stool specimens from diarrheal children and elderly individuals were collected from clinics and hospitals within the rural communities of the region over a period of 21 months (February 2017-November 2018). Commercial enzyme-immuno-assays were used for the detection of Rotavirus and Cryptosporidium pathogens from processed diarrheal stool specimens.

Results: A total of 53 fresh stool samples from diarrheal patients were screened and $36 \%$ of the diarrheagenic stool specimens tested positive for Group A Rotavirus antigens, while 5.7\% tested positive for Cryptosporidium antigens. Our findings reveal Rotavirus and Cryptosporidium pathogens as important etiological agents associated with diarrheal illnesses in children, among the rural hinterlands of the Amathole District Municipality.
\end{abstract}

Keywords: Rotavirus, Cryptosporidium, Gastroenteritis, Etiology, Enzyme immunoassay

\section{Introduction}

Several microbial agents have been implicated in diarrheal illnesses and these include bacteria, parasites, and viruses, with the latter being notably the most reported agent over the years [1-4]. Rotaviruses (RoV's) are the most prevalent etiological agents of severe diarrheal illnesses in children with more than 600,000 deaths reported annually in developing countries [5-9]. The majority of mortalities due to rotavirus infections have reverberated in sub-Saharan Africa, the Indian Subcontinent and Latin Americas [10, 11]. Over 2 million

\footnotetext{
*Correspondence: LMsolo@ufh.ac.za

${ }^{2}$ Applied and Environmental Microbiology Research Group, Department

of Biochemistry and Microbiology, University of Fort Hare, Alice 5700,

Eastern Cape, South Africa

Full list of author information is available at the end of the article
}

children worldwide are hospitalized because of RoV infections where about $90 \%$ of the mortalities are recorded among African and Asian regions each year [12]. Pathogenic parasites remain sixth in the pool of the agents of most detrimental human infectious illnesses, with protozoa being the most common in foodborne epidemics [13]. Cryptosporidium, Giardia, and Cyclospora are pervasive in nature, and have been found in the small intestines and stomach of mammals and are associated with numerous foodborne outbreaks of diarrheal illnesses in developing countries $[14,15]$. In sub-Saharan Africa and South Asia, an estimated 2.9 and 4.7 million cryptosporidiosis cases in children less than 2 years old resulted in approximately 202,000 combined annual fatalities, thus accentuating a tremendous health burden in those regions [16]. The epidemiology on the plethora 
of Rotavirus and Cryptosporidium infections worldwide is prodigious, however; there are still considerable data gaps in some parts of the world especially the southern parts of South Africa, hence, we evaluated the incidence of Rotavirus and Cryptosporidium infections among diarrheal patients in some rural settlements in the Amathole District Municipality, Eastern Cape, South Africa.

\section{Main text Methods \\ Study site description}

Despite its rural hinterlands, the Amathole District Municipality (ADM) has a relatively high population density of over 880,790 thousand people which is about $12 \%$ of the overall population within the province. Significant improvements have been made over the years with respect to water and sanitation in the region, however, about $24 \%$ of households in the district still access water from natural water sources including dams, rivers, lakes and household still have significant challenges as far as sanitation is concerned, recording an appallingly high rate of households with no sanitation [17]. This unfortunate state gives a fundamental insight on the high risk of exposure of the local dwellers within these settlements as these natural waters are the most important transmission vehicles of microbes responsible for diarrheal illnesses.

\section{Case definition and Sample collection}

Diarrheal stool samples were collected from participating patients of all ages who exhibited signs of mild to severe diarrhea and were admitted in both private and public medical facilities situated within or in close proximity to some of the selected rural communities in the ADM of the Eastern Cape Province, and with clear understanding that some patients came from remote areas where medical services and other basic needs such as sanitation and clean water supply were deficient, and had to travel long distances to acquire medical attention.

Samples were collected in sterile screw-capped $50 \mathrm{ml}$ size Falcon tubes and transported in cooler boxes to the Applied and Environmental Microbiology Research Group (AEMREG) laboratory at the University of Fort Hare, for analysis within $6 \mathrm{~h}$ of collection. Stool specimens that were fortuitously unsealed in the course of collection and upon arrival to the laboratory before processing were withdrawn from this study.

\section{Sample processing}

Stool specimens were stored in physiologically buffered saline (PBS) and temporarily stored at $2-8{ }^{\circ} \mathrm{C}$, before the commencement of the assays. The PBS stored samples were used to make $10 \%$ dilutions as per the requirements outlined in the Manufacturer's manual for both Rotavirus and Cryptosporidium immunoassay kits.

\section{In vitro qualitative immunoassay test for detection of viral and parasitic pathogens}

ProSpecT $T^{\mathrm{T}}$ Rotavirus microplate assay The commercial ProSpec $\mathrm{T}^{\mathrm{TM}}$ Rotavirus test which utilizes a polyclonal antibody in a solid-phase sandwich enzyme immunoassay to detect group-specific antigen present in Group A rotaviruses was used, following manufacturer's instructions. The relative sensitivity and specificity of the test is $98.7 \%$ and $99.2 \%$ respectively.

Remel Xpect ${ }^{\circledR}$ Giardia/Cryptosporidium test The commercial Remel Xpect ${ }^{\circledR}$ Giardia/Cryptosporidium test is a qualitative chromatographic immunoassay that detects the presence of parasitic Giardia and Cryptosporidium antigens in preserved and unpreserved fecal specimens. This test is rapid and simple to use, with the specificity of about $99 \%$ and sensitivity of about $96 \%$ and the results are easy to interpret and obtainable within $15 \mathrm{~min}$ if carried out correctly.

\section{Results}

\section{Detection of Rotavirus antigens}

Stool specimens that retained the intense color after the addition of wash buffer were indicative of the presence of these Rotavirus antigens and the absorbance of the positive stool specimens recorded ranged from a minimum of 0.323 to a maximum of 2.906 absorbance units.

A total of 19 (36\%) of the tested diarrheagenic stool samples (53) were positive for the Group A Rotavirus. Among the 19 positive specimens, 4 (8\%) were obtained from adults and 15 (28\%) specimens were recovered from children less than 6 years, thus confirming the predominance of Rotavirus infections in pediatrics.

\section{Detection of Cryptosporidium antigens}

Three (5.7\%) diarrheagenic stool samples from 53 diarrheal patients were positive for Cryptosporidium antigens and this suggests an infection by this parasite, which has been implicated as one of the causes of gastroenteritis [18]. None of the stool specimens tested positive for Giardia.

\section{Discussion}

Despite improvements on the development of Rotavirus vaccines over the years, which benefit mostly the privileged countries and leaving the less fortunate in despair, Rotavirus in these regions remains one of the peak causes of childhood diarrhea, with an estimated 2.3 million hospitalizations and nearly 527,000 mortalities in children every year especially in destitute countries [19]. 
The global disease burden and the socio-economic stress brought upon families and the society at large by these Rotavirus infections can never be overemphasized, hence the use of rapid immune-assay for surveillance of these infections is necessary, so as to halt its epidemics [20,21].

In a similar study by Omoruyi et al. [22], the degree of detection of Cryptosporidium parasites among HIVpatients with diarrhea using the immunoassay methods, was considerably high when compared to Ziehl-Neelsen (ZN) staining methods and surprisingly; Polymerase
Chain Reaction (PCR) methods. This revelation also accentuates the importance of chromatographic immunoassays in the screening of clinical samples.

The majority of positive patients were children less than 6 years of age; four patients were adults of which two were diabetic (Table 1). Co-Infection was observed from 2 (3.8\%) patients (MHC 03 and $\mathrm{KH} \mathrm{04)} \mathrm{which} \mathrm{may}$ pose an exacerbated diarrheal condition. Prevalence of Cryptosporidium among diarrheal specimen collected from a pediatric hospital in Iran has been previously

Table 1 Demographic data of the patients who tested positive for Cryptosporidium and Rotavirus pathogens

\begin{tabular}{|c|c|c|c|c|c|c|c|c|c|}
\hline Patient(s) & $\begin{array}{l}\text { Age } \\
\text { range } \\
\text { (years) } \\
\leq 5 / 6- \\
40 / \geq 41\end{array}$ & $\begin{array}{l}\text { Type } \\
\text { of locality } \\
\text { (rural/ } \\
\text { semi-rural/ } \\
\text { peri-urban/ } \\
\text { urban) }\end{array}$ & $\begin{array}{l}\text { Source } \\
\text { of income } \\
\text { (employment) }\end{array}$ & $\begin{array}{l}\text { Total no. } \\
\text { of individuals } \\
\text { per household }\end{array}$ & $\begin{array}{l}\text { Source } \\
\text { of water/ } \\
\text { storage }\end{array}$ & $\begin{array}{l}\text { Type } \\
\text { of sanitary } \\
\text { system } \\
\text { (toilets/ } \\
\text { restrooms/ } \\
\text { lavatories) }\end{array}$ & $\begin{array}{l}\text { Distance } \\
\text { to the nearest } \\
\text { medical centre/ } \\
\text { clinic/Hospital } \\
(\mathrm{km})\end{array}$ & $\begin{array}{l}\text { History of diarrhea } \\
\text { within the household } \\
\text { and period } \\
\text { of diagnosis }\end{array}$ & $\begin{array}{l}\text { Immune/ } \\
\text { health } \\
\text { status }\end{array}$ \\
\hline P04 & $\geq 41$ & Rural & Social grant & 8 & $\begin{array}{l}\text { Tap/storage } \\
\text { tanks }\end{array}$ & $\begin{array}{c}\text { Flushable } \\
\text { toilets }\end{array}$ & $\approx 5$ & Yes/3 days & Diabetic \\
\hline P01 & $\geq 41$ & Rural & Social grant & 8 & $\begin{array}{l}\text { Tap/storage } \\
\text { tanks }\end{array}$ & $\begin{array}{c}\text { Flushable } \\
\text { toilet }\end{array}$ & $\approx 5$ & No & Diabetic \\
\hline P03 & $\leq 5$ & Rural & - & 3 & Tap & Pit toilet & $\approx 8$ & No & Healthy \\
\hline P 07 & $6-40$ & Rural & Social grant & 6 & $\begin{array}{l}\text { Tap and } \\
\text { storage } \\
\text { tanks }\end{array}$ & $\begin{array}{c}\text { Flushable } \\
\text { toilet }\end{array}$ & $\approx 12$ & No & $\begin{array}{l}\text { Undis- } \\
\text { closed }\end{array}$ \\
\hline $\mathrm{KH} 01$ & $\leq 5$ & Rural & - & 11 & Tap & $\begin{array}{c}\text { Flushable } \\
\text { toilets }\end{array}$ & 4 & No & Healthy \\
\hline $\mathrm{KHO3}$ & $\leq 5$ & Rural & - & 4 & Tap & $\begin{array}{c}\text { Flushable } \\
\text { toilets }\end{array}$ & $\approx 8$ & No & Healthy \\
\hline $\mathrm{KH} 04$ & $\leq 5$ & Rural & - & 8 & Tap & $\begin{array}{c}\text { Flushable } \\
\text { toilets }\end{array}$ & $\approx 4$ & No & Healthy \\
\hline $\mathrm{KH} 05$ & $\leq 5$ & Peri-urban & - & 7 & Tap & $\begin{array}{l}\text { In-house } \\
\text { restroom }\end{array}$ & $\approx 1$ & No & Healthy \\
\hline $\mathrm{KH} 07$ & $\leq 5$ & Rural & - & 6 & Tap & $\begin{array}{c}\text { Flushable } \\
\text { toilets }\end{array}$ & $\approx 3$ & No & Healthy \\
\hline $\mathrm{KH} 10$ & $\leq 5$ & Rural & Social grant & 4 & Tap & Pit toilet & $\approx 8$ & No & $\begin{array}{l}\text { Undis- } \\
\text { closed }\end{array}$ \\
\hline $\mathrm{KH} 12$ & $\leq 5$ & Rural & - & 9 & Tap & $\begin{array}{c}\text { Flushable } \\
\text { toilets }\end{array}$ & $\approx 8$ & No & Healthy \\
\hline $\mathrm{KH} 13$ & $6-40$ & Semi-rural & - & 10 & $\begin{array}{l}\text { Tap/storage } \\
\text { tanks }\end{array}$ & $\begin{array}{c}\text { Flushable } \\
\text { toilet }\end{array}$ & $\approx 4$ & No & $\begin{array}{l}\text { Undis- } \\
\text { closed }\end{array}$ \\
\hline MHC 02 & $\leq 5$ & Rural & Social grant & 8 & $\begin{array}{l}\text { Tap/storage } \\
\text { tank }\end{array}$ & $\begin{array}{l}\text { In-house } \\
\text { restroom }\end{array}$ & $\approx 1$ & No & - \\
\hline MHC 03 & $\leq 5$ & Rural & Social grant & 8 & Tap & Pit toilet & $\approx 7$ & Yes/2 days & - \\
\hline MHC 04 & $\leq 5$ & Rural & Social grant & 5 & Tap & $\begin{array}{c}\text { Flushable } \\
\text { toilet }\end{array}$ & $\approx 5$ & No & - \\
\hline MHC 06 & $\leq 5$ & Rural & Social grant & 5 & $\begin{array}{l}\text { Tap/storage } \\
\text { tanks }\end{array}$ & $\begin{array}{c}\text { Flushable } \\
\text { toilet }\end{array}$ & $\approx 5$ & Yes/2 days & - \\
\hline Vic 02 & $\leq 5$ & Semi-rural & - & 8 & $\begin{array}{l}\text { Tap/storage } \\
\text { tanks }\end{array}$ & $\begin{array}{c}\text { Flushable } \\
\text { toilet }\end{array}$ & $\approx 2$ & No & - \\
\hline Vic 04 & $6-40$ & Semi-rural & - & 9 & $\begin{array}{l}\text { Tap/storage } \\
\text { tanks }\end{array}$ & $\begin{array}{c}\text { Flushable } \\
\text { toilet }\end{array}$ & $\approx 2$ & Yes & Healthy \\
\hline Vic 06 & $\leq 5$ & Semi-rural & - & 4 & Tap & $\begin{array}{c}\text { Flushable } \\
\text { toilet }\end{array}$ & $\approx 2$ & No & Healthy \\
\hline UN 01 & $6-40$ & Rural & Unemployed & 8 & $\begin{array}{c}\text { Storage } \\
\text { tanks }\end{array}$ & Pit toilet & $\approx 8$ & No & $\begin{array}{l}\text { Undis- } \\
\text { closed }\end{array}$ \\
\hline R07 & $\geq 41$ & Peri-urban & Employed & 5 & $\begin{array}{r}\text { Storage } \\
\text { tanks }\end{array}$ & $\begin{array}{c}\text { Flushable } \\
\text { toilet }\end{array}$ & $\approx 2$ & Yes & $\begin{array}{l}\text { Undis- } \\
\text { closed }\end{array}$ \\
\hline
\end{tabular}


reported [23], which corroborates the findings of our present study.

Though the immunoassays used in this study have been proven to be expedient, simple, rapid and results obtainable timeously, however, numerous studies have highlighted the necessity for further molecular investigations as paramount for extensive and indisputable detection of these pathogens [24]. Nonetheless; previous studies have recommended the utilization of rapid immunoassay tests for timeous and effective therapy [25]. Furthermore, the use of such tests ensures that accuracy and efficiency are maintained throughout the diagnosis of enteric pathogens especially in situations where there is a lack of resources, labor and time [26]. Polymerase Chain Reaction (PCR) techniques continue to champion the diagnosis of Cryptosporidium infections owing to their improved sensitivity and specificity, however, these methods are of restricted applicability due to their costs, high technical expertise demand and special equipment required, which then seclude the less fortunate countries from indulging on such techniques [22]. In a study conducted in one of the provinces of South Africa, a prevalence of about $43 \%$ of Cryptosporidium species was obtained in surface waters, which were primarily used for irrigation and other domestic purposes [27]. These findings highlight the association of this pathogen with environmental waters and subsequently fresh produce, thereby accenting the risk of exposure of humans who utilize these waters. Furthermore, the steadiness of enteric parasites in the environment suggests that open water sources with a high possibility of anthropogenic, wildlife and livestock interactions may exacerbate the risk of cryptosporidiosis of public health importance [28]. The efficacy of Enzyme Immuno Assays (EIA) in the diagnoses of various microbial pathogens is seen by others to be inefficient compared to other methods like Reverse Transcription-Polymerase Chain Reaction (RTPCR). However, previous studies have complete corroboration between both methods [29], thereby validating the efficiency of the detection method used in this study. Moreover, these techniques are less time consuming with high sensitivity and specificity, making it one of the most valuable rapid methods of detection in vitro. Our findings further corroborate those of another report and are in support of the notion that modern immune-assays serves as a good alternative in diagnoses of clinical infections [30]. Several studies have fallen short in relating rotavirus-mediated diseases with climatic conditions [5] and likewise, this current study could not draw a precise conclusion in relation to climate conditions, since specimens and cases were obtained irrespective of the season nor climate condition. Among the provinces in South Africa, the Eastern Cape is one of the poorest of the 9 provinces; comprising of a number of rural and informal settlements with poor infrastructure and limited or no access to basic services such as health care facilities, proper hygiene and adequate sanitation practices, potable and safe drinking water; leaving the populace in this province at the highest risk of exposure to numerous food and water-borne diseases (including diarrhea), thus constituting a serious public and environmental health burden, and subsequently a severe strain in socio-economic lifestyle in the province.

\section{Conclusion}

Rotavirus and Cryptosporidium pathogens are gastroenteritis agents capable of causing a series of diarrheal episodes predominantly in children less than six years of age. This revelation is largely demonstrated in regions with less to complete lack of resources and campaigns for serious and insightful concerns about public health. The prevalence of Rotavirus and Cryptosporidium enteric pathogens highlighted in this study from the rural hinterlands of the Eastern Cape Province justifies the need for cross-sectional and collaborative strategies from the higher authorities to implement as a matter of urgency the provision and distribution of vaccines as to combat the dissemination of these enteric pathogens. There is a need for extension of alms from public health sectors so as to reach even the utmost remote areas where these infections are endemic and providing the critically needed services in order to ameliorate this plight.

\section{Future prospects}

Exploration of more gastroenteritis agents in a larger population is paramount in unwinding and understanding the trends, eco-distribution of these etiologic agents and defining their roles, so as to minimize the therapeutic and public health burden they pose. Furthermore; molecular characterization of these etiological agents is imperative as a means of understanding the mechanisms of action encompassed by these enteric pathogens at a cellular and molecular level.

\section{Limitations}

- One of the outstanding challenges encountered in the course of our study was the reluctance of some patients to partake in the study, by declining or prohibiting us to take samples from them even though they exhibited signs and symptoms or were diagnosed with diarrheal illness. An overall sum of 12 individuals declined to be included in this study even though they presented symptoms of diarrhea.

- This then resulted in the acquisition of fewer than expected specimens, though reports from medical 
midwives revealed considerable amounts of cases or hospitalizations in the regions under study. Stool specimens that were found unsealed in the course of collection and upon arrival to the Laboratory were withdrawn from this study.

- Also; it became apparent that some individuals fail to seek medical attention even though exhibiting signs of the illness, this is mainly due to the extended distances to health facilities, and hence some cases may have been missed or misdiagnosed.

\begin{abstract}
Abbreviations
AG: Acute Gastroenteritis; ADM: Amathole District Municipality; AEMREG: Applied and Environmental Microbiology Research Group; AMGDS: Amathole Municipality Growth and Development Summit; HIV: Human immunodeficiency virus; PBS: Physiological buffered saline; EIA: Enzyme immuno assays; PCR: Polymerase chain reaction; RT-PCR: Reverse transcription-polymerase chain reaction; ZN: Ziehl-Neelsen.
\end{abstract}

\section{Acknowledgements}

We are grateful to the South African Medical Research Council (Grant no. SAMRC/UFH/P790) and the National Research Foundation (102463) of South Africa for financial support.

\section{Authors' contributions}

LM was the main researcher who contributed to the origin, overall idea and study design including the collection of data, interpretation, and analysis of results and also prepared the manuscript and is the corresponding author. $\mathrm{BCl}$ and $\mathrm{AIO}$ oversaw the study, contributed to data analysis and interpretation, drafted the manuscript. All authors read and approved the final manuscript.

\section{Funding}

We would like to thank the South African Medical Research Council (SAMRC) and the National Research Foundation (NRF) for funding this work, particularly with respect to bursary award, purchase of consumables and analysis of this study.

\section{Availability of data and materials}

Data will be made available on reasonable request.

\section{Ethics approval and consent to participate}

The ethical approval was obtained from the University of Fort Hare Ethics committee with certificate reference number: IWE001, the approval to conduct this research was obtained from the Department of Health, Eastern Cape Province, South Africa while the permission to collect sample was sought from the patients through verbal informed consent with the adult participants and in the case of children, permission was granted by parent(s)/guardian(s) and/or caregivers of enrolled children prior to enrolment. The anonymity of patient's records (names etc.) was maintained.

\section{Consent for publication}

Not Applicable. This manuscript does not contain data from any other person.

\section{Competing interests}

The authors declare that they have no competing interests.

\section{Author details}

1 SA-MRC Microbial Water Quality Monitoring Centre, University of Fort Hare, Private Bag X1314, Alice 5700, Eastern Cape, South Africa. ${ }^{2}$ Applied and Environmental Microbiology Research Group, Department of Biochemistry and Microbiology, University of Fort Hare, Alice 5700, Eastern Cape, South Africa. ${ }^{3}$ Sefako Makgatho Health Sciences University, Ga-Rankuwa, Pretoria, Gauteng, South Africa.
Received: 13 November 2019 Accepted: 17 March 2020

Published online: 30 March 2020

\section{References}

1. Nguyen TV, Le Van P, Le Huy C, Weintraub A. Diarrhoea caused by rotavirus in children less than 5 years of age in Hanoi, Vietnam. J Clin Microbiol. 2004:42(12):5745-50

2. Braeye T, De Schrijver K, Wollants E, Van Ranst M, Verhaegen J. A large community outbreak of gastroenteritis associated with consumption of drinking water contaminated by river water, Belgium, 2010. Epidemiol Infect. 2015;143(4):711-9.

3. Humphries RM, Linscott AJ. Laboratory diagnosis of bacterial gastroenteritis. Clin Microbiol Rev. 2015;28(1):3.

4. Bruzzese E, Giannattasio A, Guarino A. Antibiotic treatment of acute gastroenteritis in children. F1000Research. 2018;7:193.

5. Hashizume M, Armstrong B, Wagatsuma Y, Faruque ASG, Hayashi T, Sack DA. Rotavirus infections and climate variability in Dhaka, Bangladesh: a time-series analysis. Epidemiol Infect. 2008;136(9):1281-9.

6. Zaman K, Anh DD, Victor JC, Shin S, Yunus M, Dallas MJ, Podder G, Thiem VD, Luby SP, Coia ML, Lewis K. Efficacy of pentavalent rotavirus vaccine against severe rotavirus gastroenteritis in infants in developing countries in Asia: a randomised, double-blind, placebo-controlled trial. Lancet. 2010;376(9741):615-23.

7. Gladstone BP, Ramani S, Mukhopadhya I, Muliyil J, Sarkar R, Rehman AM, Jaffar S, Gomara MI, Gray JJ, Brown DW, Desselberger U. Protective effect of natural rotavirus infection in an Indian birth cohort. N Engl J Med. 2011;365(4):337-46.

8. Chen SC, Tan LB, Huang LM, Chen KT. Rotavirus infection and the current status of rotavirus vaccines. J Formos Med Assoc. 2012;111(4):183-93.

9. He B, Huang X, Zhang F, Tan W, Matthijnssens J, Qin S, Xu L, Zhao Z, Wang Q, Hu T, Bao X. Group A rotaviruses in Chinese bats: genetic composition, serology and evidence for bat-to-human transmission and reassortment. J Virol. 2017;91:e02493.

10. Siddique AK, Ahmed S, lqbal A, Sobhan A, Poddar G, Azim T, Sack DA, Rahman M, Sack RB. Epidemiology of rotavirus and cholera in children aged less than five years in rural Bangladesh. J Health Popul Nutr. 2011:29(1):1.

11. Madhi SA, Cunliffe NA, Steele D, Witte D, Kirsten M, Louw C, Ngwira B, Victor JC, Gillard PH, Cheuvart BB, Han HH. Research article (new england journal of medicine) effect of human rotavirus vaccine on severe diarrhoea in African infants. Malawi Med J. 2016;28(3):108-14.

12. Alam MM, Khurshid A, Shaukat S, Suleman RM, Sharif S, Angez M, Malik SA, Ahmed TM, Aamir UB, Naeem M, Zaidi SSZ. Epidemiology and genetic diversity of rotavirus strains in children with acute gastroenteritis in Lahore, Pakistan. PLoS ONE. 2013;8(6):e67998.

13. Fallah AA, Pirali-Kheirabadi K, Shirvani F, Saei-Dehkordi SS. Prevalence of parasitic contamination in vegetables used for raw consumption in Shahrekord, Iran: influence of season and washing procedure. Food Control. 2012;25(2):617-20.

14. Thompson RCA, Ash A. Molecular epidemiology of Giardia and Cryptosporidium infections. Infect Genet Evol. 2016:40:315-23.

15. Dixon BR. Parasitic illnesses associated with the consumption of fresh produce-an emerging issue in developed countries. Curr Opin Food Sci. 2016;8:104-9.

16. Sow SO, Muhsen K, Nasrin D, Blackwelder WC, Wu Y, Farag TH, Panchalingam S, Sur D, Zaidi AK, Faruque AS, Saha D. The burden of Cryptosporidium diarrhoeal disease among children $<24$ months of age in moderate/high mortality regions of Sub-Saharan Africa and South Asia, utilizing data from the Global Enteric Multicenter Study (GEMS). PLoS Negl Trop Dis. 2016;10(5):e0004729.

17. Amathole District Municipality Growth and Development Summit (ADM GDS) (2007). Socio-economic profile. www.ecsecc.org. Accessed 24 Aug 2018.

18. Chalmers RM, Davies AP. Minireview: clinical cryptosporidiosis. Exp Parasitol. 2010;124(1):138-46.

19. Latipov R, Utegenova E, Kuatbayeva A, Kasymbekova K, Abdykarimov $\mathrm{S}$, Juraev R, Ismailov U, Flem E. Epidemiology and burden of rotavirus disease in Central Asia. Int J Infect Dis. 2011;15(7):e464-9. 
20. Gray J, Vesikari T, Van Damme P, Giaquinto C, Mrukowicz J, Guarino A, Dagan R, Szajewska H, Usonis V. Rotavirus. J Pediatr Gastroenterol Nutr. 2008;46:S24-31

21. Gautam R, Lyde F, Esona MD, Quaye O, Bowen MD. Comparison of Premier ${ }^{\mathrm{TM}}$ Rotaclone $^{\circledR}$, ProSpec $^{\mathrm{TM}}$, and RIDASCREEN ${ }^{\circledR}$ rotavirus enzyme immunoassay kits for detection of rotavirus antigen in stool specimens. J Clin Virol. 2013;58(1):292-4.

22. Omoruyi BE, Nwodo UU, Udem CS, Okonkwo FO. Comparative diagnostic techniques for Cryptosporidium infection. Molecules. 2014:19(2):2674-83.

23. Tahvildar-Biderouni F, Salehi N. Detection of Cryptosporidium infection by modified Ziehl-Neelsen and PCR methods in children with diarrheal samples in pediatric hospitals in Tehran. Gastroenterol Hepatol Bed Bench. 2014;7(2):125.

24. Alexander $\mathrm{CL}$, Niebel $\mathrm{M}$, Jones $\mathrm{B}$. The rapid detection of Cryptosporidium and Giardia species in clinical stools using the Quik Chek immunoassay. Parasitol Int. 2013;62(6):552-3.

25. Van den Bossche D, Cnops L, Verschueren J, Van Esbroeck M. Comparison of four rapid diagnostic tests, ELISA, microscopy and PCR for the detection of Giardia lamblia, Cryptosporidium spp. and Entamoeba histolytica in feces. J Microbiol Methods. 2015;110:78-84.

26. Minak J, Kabir M, Mahmud I, Liu Y, Liu L, Haque R, Petri WA. Evaluation of rapid antigen point-of-care tests for the detection of Giardia and Cryptosporidium in human fecal specimens. J Clin Microbiol. 2011;50:154-6.

27. Duhain GLMC. Occurrence of Cryptosporidium spp. in South African irrigation waters and survival of Cryptosporidium parvum during vegetable processing. PhD Dissertation, University of Pretoria. 2012

28. Samra NA, Jori F, Cacciò SM, Frean J, Poonsamy B, Thompson PN. Cryptosporidium genotypes in children and calves living at the wildlife or livestock interface of the Kruger National Park, South Africa. Onderstepoort J Vet Res. 2016;83(1):1-7.

29. Sai L, Sun J, Shao L, Chen S, Liu H, Ma L. Epidemiology and clinical features of rotavirus and norovirus infection among children in Ji'nan, China. Virol J. 2013;10(1):1.

30. Dusetty P, Velázquez FR, Gutiérrez-Escolano AL, Ludert JE. Evaluation of the second generation of a commercial latex agglutination test for the detection of rotavirus antigens in fecal samples. J Clin Virol. 2013;57(1):88-90.

\section{Publisher's Note}

Springer Nature remains neutral with regard to jurisdictional claims in published maps and institutional affiliations.
Ready to submit your research? Choose BMC and benefit from:

- fast, convenient online submission

- thorough peer review by experienced researchers in your field

- rapid publication on acceptance

- support for research data, including large and complex data types

- gold Open Access which fosters wider collaboration and increased citations

- maximum visibility for your research: over $100 \mathrm{M}$ website views per year

At BMC, research is always in progress.

Learn more biomedcentral.com/submissions 